\title{
Increased Ferritin Gene Expression in Atherosclerotic Lesions
}

\author{
Jong-Hwei S. Pang, ${ }^{\star}$ Meei-Jyh Jiang, ${ }^{*}$ Yuh-Lien Chen, ${ }^{\ddagger}$ Fu-Wen Wang, ${ }^{\ddagger}$ Danny L. Wang, ${ }^{*}$ Shu-Hsun Chu, ${ }^{\S}$ \\ and Lee-Young Chau* \\ *Division of Cardiovascular Research, Institute of Biomedical Sciences, Academia Sinica, Nankang, Taipei 11529; ${ }^{\ddagger}$ Institute of Anatomy, \\ National Yang-Ming University, Shih-Pai, Taipei 11221; and ${ }^{\S}$ Department of Surgery, National Taiwan University Hospital, Taipei 10018, \\ Taiwan, Republic of China
}

\begin{abstract}
To identify genes potentially implicated in atherogenesis, a cDNA library was constructed from human atherosclerotic aorta and differentially screened with ${ }^{32} \mathrm{P}$-labeled-cDNAs prepared from human normal and atherosclerotic aortas. Two cDNA clones exhibiting higher hybridization to the ${ }^{32}$ P-labeled cDNAs from atherosclerotic vessels were isolated and identified to be genes encoding L-ferritin and $\mathrm{H}$-ferritin, respectively. Northern blot analysis confirmed that the expression of both ferritin genes was notably higher in human and rabbit atherosclerotic aortas than in their normal counterparts. A time-course study illustrated that both $\mathrm{L}$ - and $\mathrm{H}$-ferritin mRNAs were markedly increased in aortas of rabbits after feeding with a high cholesterol diet for $6 \mathrm{wk}$, which was also the time period after which the formation of lesions became evident. In situ hybridization revealed that both $\mathrm{L}$ - and $\mathrm{H}$-ferritin mRNAs were induced in endothelial cells and macrophages of human early lesions. The signals were also detected in the smooth muscle cells of advanced lesions. Immunostaining further identified the presence of ferritin protein in atherosclerotic lesions. On the other hand, Prussian blue stain revealed the presence of iron deposits in advanced lesions but not in early human or rabbit lesions. Further experiments with cultured human monocytic THP-1 cells and aortic smooth muscle cells demonstrated that ferritin mRNAs were subjected to up-regulation by treatment with IL-1 or TNF, while TGF, PDGF, and oxidized LDL did not affect the expression of either ferritin gene in both cell lines. Collectively, these results clearly demonstrate that ferritin genes are susceptible to induction in the course of plaque formation. (J. Clin. Invest. 1996. 97: 2204-2212.) Key words: L-ferritin • H-ferritin • atherosclerosis • iron • cytokines
\end{abstract}

\section{Introduction}

Atherosclerosis is a pathological process which eventually leads to the obstruction of blood vessels. The development of atherosclerotic lesions is believed to be initiated by injury of the endothelium, followed by activation and infiltration of monocytes and T-lymphocytes, and differentiation of monocytes

Address correspondence to Lee-Young Chau, Institute of Biomedical Sciences, Academia Sinica, Nankang, Taipei, 11529, Taiwan, R.O.C. Phone: 866-2-789-9137; FAX: 886-2-785-3569, 886-2-782-5573.

Received for publication 19 January 1995 and accepted in revised form 27 February 1996.

J. Clin. Invest.

(C) The American Society for Clinical Investigation, Inc.

0021-9738/96/05/2204/09 \$2.00

Volume 97, Number 10, May 1996, 2204-2212 into macrophages in the subendothelium $(1,2)$. Subsequently, plaques are formed, and these are characterized by the accumulation of lipid droplets in foam cells derived from macrophages and smooth muscle cells, the proliferation of smooth muscle cells, and the accumulation of matrix proteins in the extracellular spaces, which leads to the thickening of the intima $(1,2)$. Activation of the vascular endothelial cells and smooth muscle cells as well as other inflammatory cell components appears to be essential to the initiation and progression of plaque formation. Alteration in expression of genes encoding growth factors (3-6), receptors (5-8), adhesion molecules (9-11), cytokines $(3,4)$, chemoattractants $(12,13)$ and matrix-associated proteins (14-16) has been shown to be implicated in atherogenesis. Due to the disease's complex and multifactorial nature, many genes which are not presently uncovered may also play important roles in the course of plaque formation. In an attempt to identify such atherosclerosis-associated genes, we have constructed a cDNA library from human atherosclerotic aorta. Differential screening of this library with cDNAs prepared from poly $\left(\mathrm{A}^{+}\right)$RNAs of human normal and atherosclerotic aortas has allowed us to isolate cDNA clones which are highly expressed in the disease state. Here we report the identification of two cDNA clones which encode the iron-binding proteins, L-ferritin and $\mathrm{H}$-ferritin (17), from the differential screening. Northern blot analysis and in situ hybridization demonstrated that these two genes are highly induced in atherosclerotic lesions of humans and rabbits. Since alterations in ferritin expression would obviously affect the intracellular iron availability which in turn has a great impact on many metabolic processes in cells, the present finding implies that these cellular iron-binding proteins play a role in the progression of the disease.

\section{Methods}

Human tissue samples. Samples of human atherosclerotic aortas were obtained during surgery from patients $(n=6)$ with abdominal aneurysm. Normal aortas and aortas with early fatty streaks were obtained from organ donors $(n=2)$ for heart transplantation or from patients $(n=4)$ during bypass surgery. Tissue samples were immediately rinsed with ice-cold saline solution and immediately frozen in liquid nitrogen for RNA isolation or immersion-fixed with $4 \%$ paraformaldehyde then paraffin-embedded for hematoxylin-eosin staining or other experiments. For cDNA library construction, the poly $\left(\mathrm{A}^{+}\right)$ RNA isolated from an abdominal aortic aneurysm was used. The tissue sections prepared from three ascending aortas (early lesions) and four abdominal aortas (advanced fibrous lesions) were examined and used for in situ hybridization, immunocytochemistry, and iron-histochemistry.

Experimental animals. New Zealand White male rabbits $(2 \mathrm{~kg}$ body wt) were fed with either regular feed, regular feed supplemented with $6 \%$ corn oil, or regular feed supplemented with $6 \%$ corn oil and $2 \%$ cholesterol for 1-6 wk. Each group consisted of four age-matched animals. Animals were anesthetized with i.v. injection of $35-40 \mathrm{mg} / \mathrm{kg}$ sodium pentobarbital. Aortas were removed, rinsed with ice-cold sa- 
line, and immediately frozen for RNA isolation or fixed with paraformaldehyde as described above.

RNA isolation and library construction. Total RNA of aortas were isolated as described by Chomczynski and Sacchi (18). For isolation of poly $\left(\mathrm{A}^{+}\right) \mathrm{RNA}$, the total RNA was applied onto an oligo(dT)-cellulose column and poly $\left(\mathrm{A}^{+}\right) \mathrm{RNA}$ was eluted (19). Synthesis of the first and second strands of cDNA was carried out using a cDNA synthesis kit following the protocol provided by the manufacturer (Bethesda Research Laboratories, Gaithersburg, MD). To construct the human atherosclerotic aorta cDNA library, the blunt-ended cDNA prepared from the human atherosclerotic aorta was ligated with EcoRI adaptor followed by cloning into the lambda gt11 arms. The ligated recombinant lambda phages were packaged and transfected into the host cell Y1090. Before screening, the library was amplified once and stored in the presence of $7 \%$ DMSO at $-70^{\circ} \mathrm{C}$.

Differential screening of the cDNA library. For differential screening, aliquots of the human atherosclerotic aorta cDNA library were plated out on $100-\mathrm{mm}$ plates at a density of $500-600$ pfu per plate. Bacteriophage infection and plating of infected Escherichia coli onto plates were carried out accordingly (20). The plates were incubated at $37^{\circ} \mathrm{C}$ until plaques were visible. Colonies were transferred onto nylon filters and lysed. Filters were first hybridized to ${ }^{32} \mathrm{P}$-labeled cDNA synthesized from normal human aorta mRNA as described above and labeled with $\left[\alpha{ }^{32} \mathrm{P}\right] \mathrm{dCTP}$ by random priming (Amersham Corp., Little Chalfont, England) under conditions as described in "Northern blot analysis." After autoradiography, probes on the filters were stripped off by boiling in $0.1 \%$ SDS for $5 \mathrm{~min}$. Filters were immediately hybridized to ${ }^{32} \mathrm{P}$-labeled cDNA synthesized from human atherosclerotic aorta mRNA. Colonies which showed stronger signals (greater than fivefold) from hybridization with the atherosclerotic lesion probes were further analyzed.

DNA sequencing. The cDNA insert of the isolated phage clone was amplified with a pair of lambda gt11 primers flanking the EcoRI cloning site. An aliquot from the phage lysate was denatured at $95^{\circ} \mathrm{C}$ for 5 min and then subjected to PCR with Taq polymerase. The PCR was performed by 40 cycles of denaturation at $94^{\circ} \mathrm{C}$ for $1 \mathrm{~min}$, annealing at $55^{\circ} \mathrm{C}$ for $1 \mathrm{~min}$, and extension at $72^{\circ} \mathrm{C}$ for $2 \mathrm{~min}$. Amplified cDNA was electrophoresed on a $1 \%$ agarose gel and excised from the gel. The cDNA was then extracted and purified from the gel by DNA purification kit from Qiagen Inc. (Hilden, Germany). DNA sequencing was performed on ABI 373A automated DNA sequencer by dyedeoxy terminator cycle sequencing methods according to the manufacturer's instructions. Sequence analysis was conducted using the GenBank Database in National Center for Biotechnology Information, NIH, Bethesda, MD.

Northern blot analysis. Equal amounts $(5-10 \mu \mathrm{g})$ of total RNA were denatured and electrophoresed on $1 \%$ agarose gel containing $6.6 \%$ formaldehyde for $2 \mathrm{~h}$ at $120 \mathrm{~V}$. After electrophoresis, RNA was transferred onto nylon membrane and fixed by ultraviolet irradiation. Membranes were prehybridized for at least $1 \mathrm{~h}$ at $42^{\circ} \mathrm{C}$ in prehybridization solution containing $10 \%$ dextran sulfate, $1 \%$ SDS, $50 \%$ formamide, $1 \mathrm{M} \mathrm{NaCl}$, and $1 \mathrm{mg} / \mathrm{ml}$ denatured sonicated salmon sperm DNA. ${ }^{32} \mathrm{P}$-labeled cDNA probes at $10^{6} \mathrm{cpm} / \mathrm{ml}$ were added and the hybridization was continued at $42^{\circ} \mathrm{C}$ overnight. Blots were then washed with buffer containing $2 \times \mathrm{SSC}(1 \times \mathrm{SSC}$ consisted of $150 \mathrm{mM}$ $\mathrm{NaCl}, 15 \mathrm{mM}$ Na-citrate, $\mathrm{pH} 7.0$ ) and $1 \%$ SDS for $30 \mathrm{~min}$ at $50^{\circ} \mathrm{C}$, followed by wash with buffer containing $0.2 \times$ SSC and $1 \%$ SDS for another $30 \mathrm{~min}$ at $50^{\circ} \mathrm{C}$. The blot was covered in Saran wrap to prevent drying and exposed to Kodak XAR-5 film at $-70^{\circ} \mathrm{C}$ using Kodak intensifying screen.

In-situ hybridization. L-ferritin and H-ferritin cDNAs, which contain entire coding sequences, were subcloned into pcDNA3 vector, respectively. The antisense RNA was then prepared by SP6 RNA

1. Abbreviations used in this paper: BHT, butylated hydroxytoluene; $\mathrm{DAB}, 3,3^{\prime}$-diaminobenzidine; DIG, digoxigenin; MCP-1, monocyte chemoattractant protein-1. polymerase and labeled with digoxigenin(DIG)1-UTP according to manufacturer's instructions (Boehringer Mannheim Biochemica, Mannheim, Germany) and used as probes for in situ hybridization, which was performed according to a published method (21). Paraffinembedded tissue sections (5-6- $\mu \mathrm{m}$ thick) were placed on poly-L-lysinecoated slides, deparaffinized, treated with proteinase $\mathrm{K}(1 \mu \mathrm{g} / \mathrm{ml}$ for $15 \mathrm{~min}$ at $\left.37^{\circ} \mathrm{C}\right)$ and acetylated $(0.25 \%$ acetic anhydride in $0.1 \mathrm{M}$ triethanolamine and $0.9 \% \mathrm{NaCl}$ for $10 \mathrm{~min}$ ). Sections were then washed with $2 \times$ SSC, dehydrated, and air dried for $30 \mathrm{~min}$. Before hybridization, each section was prehybridized in a humid chamber with $100 \mu \mathrm{l}$ prehybridization solution containing $5 \times$ SSC, $5 \times$ Denhardt's solution, $50 \%$ deionized formamide, $250 \mu \mathrm{g} / \mathrm{ml}$ yeast t-RNA, $250 \mu \mathrm{g}$ denatured salmon sperm DNA, and $4 \mathrm{mM}$ EDTA for $3 \mathrm{~h}$ at $50^{\circ} \mathrm{C}$. Hybridization was performed at $50^{\circ} \mathrm{C}$ for $16-24 \mathrm{~h}$ in a humid chamber with $25 \mu \mathrm{l} /$ section prehybridization solution containing $10 \mathrm{ng} / \mu \mathrm{l} \mathrm{RNA}$ probe. After the hybridization, sections were washed at $42^{\circ} \mathrm{C}$ twice in $2 \times$ SSC, once in $0.2 \times$ SSC and $0.1 \times$ SSC for 15 min per wash. Sections were then blocked $(30 \mathrm{~min})$, incubated with alkaline phosphatase-conjugated anti-DIG antibody (30 min), and detected with color solution containing $337.5 \mathrm{~g} / \mathrm{ml}$ nitroblue tetrazolium salt $/ 175 \mathrm{~g} / \mathrm{ml}$ 5-bromo-4-chloro-3-indolyl-phosphate (10-30 min) according to the manufacturer's instructions (DIG labeling and detection kit; Boehringer Mannheim Biochemica). After completion of the color reaction, each section was counterstained with carmin. In some experiments, tissue sections were hybridized with DIG-labeled sense-RNA probes, which resulted in no detectable signals.

Iron histochemistry. Iron deposits on atherosclerotic lesions were examined by Perls' Prussian blue reaction with 3,3'-diaminobenzidine (DAB) intensification (22). Briefly, after Perls' reaction, section was incubated with $0.5 \% \mathrm{DAB}$ in $0.1 \mathrm{M}$ phosphate buffer, $\mathrm{pH} 7.4$, for 20 $\mathrm{min}$, followed by $15 \mathrm{~min}$ in the same medium containing $0.005 \%$ $\mathrm{H}_{2} \mathrm{O}_{2}$. The reaction was stopped by rinsing in deionized $\mathrm{H}_{2} \mathrm{O}$ for $>30$ min and then counterstained with carmin. Negative control slide was carried out through the $\mathrm{DAB}$ intensification without preincubation with Perl's solution. No positive staining was detected in the negative control sections.

Immunohistochemistry. Immunostaining was carried out using the following antibodies purchased from DAKO Japan Co. Ltd. (Kyoto, Japan): rabbit polyclonal antibody against human ferritin; mouse $\mathrm{mAb}$ against smooth muscle cell $\alpha$-actin; mouse mAb against human macrophage CD68; and mouse $\mathrm{mAb}$ against human vWf. Tissue sections were deparaffinized, rehydrated, and blocked in PBS containing $1 \%$ BSA and $1 \%$ goat serum at room temperature for $30 \mathrm{~min}$. Incubation with primary antibody or secondary FITC-conjugated goat anti-mouse or anti-rabbit antibody (Sigma Chemical Co., St. Louis, MO) was performed at room temperature for $30 \mathrm{~min}$ followed by three 5-min washes in PBS. Negative control was performed by incubating the tissue sections with secondary antibody without pretreatment with primary antibody.

Regulation of ferritin gene expression in cultured cells. A human aorta-vascular smooth muscle cells cell line (with passage number of 11) was obtained from American Type Culture Collection (CRL-1999; Rockville, MD). Cells were grown in formulated SmGM ${ }^{\mathrm{TM}}$ medium supplemented with 5\% FBS (Clonetics, San Diego, CA) at $37^{\circ} \mathrm{C}$ in a $\mathrm{CO}_{2}$ incubator $\left(95 \%\right.$ air $\left./ 5 \% \mathrm{CO}_{2}\right)$. After reaching confluency, cells were deprived of serum in DMEM medium for $2 \mathrm{~d}$ before experiments. Human monocytic THP-1 cells were grown in RPMI 1640 medium supplemented with $10 \%$ FBS. Cells were harvested at a density of $10^{6} / \mathrm{ml}$ and used for experiments. Oxidized LDL were prepared accordingly (23) with some modification. Briefly, human LDL was isolated from plasma by sequential ultracentrifugation and desalted by Sephedex G-50 gel filtration. LDL $(0.5 \mathrm{mg} / \mathrm{ml})$ was incubated with 5 $\mu \mathrm{M} \mathrm{CuSO}_{4}$ at $37^{\circ} \mathrm{C}$ in PBS for $3 \mathrm{~h}$. The reaction was stopped by adding $1 \mathrm{mM}$ EDTA and $20 \mu \mathrm{M}$ butylated hydroxytoluene (BHT). The oxidized LDL contained $10-15 \mathrm{nmol}$ of thiobarbituric acid reactive substances as malondialdehyde equivalents per milligram of LDL protein. The contamination of bacterial lipopolysaccharide in oxidized LDL preparation was examined by E-TOXATE $^{\circledR}$ reagent 
(Sigma Chemical Co.) using E. coli 055:B5 lipopolysaccharide as a standard. Less than 0.01 endotoxin $U$ could be detected in $100 \mu \mathrm{g}$ of LDL protein. Various cytokines or oxidized LDL were added into the culture and the incubation was continued for $24 \mathrm{~h}$. Total RNAs were isolated, and Northern blots were performed as described above.

\section{Results}

Differential screening of a human atherosclerotic cDNA library. A cDNA library in phage lambda gt11 was constructed from a human abdominal aortic aneurysm. Histological examination of the aneurysm tissue revealed that it contained advanced atherosclerotic lesion associated with some degree of local chronic inflammation, which was characterized by the presence of T lymphocytes, plasma cells, and macrophages in the adventitia (24). This library presumably contains genes which are highly expressed in the disease state, including those associated with atherosclerosis. Differential screening of this library with ${ }^{32} \mathrm{P}$-labeled cDNAs from human normal and atherosclerotic aortas allowed us to identify the clones that are highly expressed in the atherosclerotic lesions. Phage clones which exhibited stronger hybridization signals with the ${ }^{32} \mathrm{P}$-labeled cDNA probes prepared from atherosclerotic vessels were picked up. After the second round of hybridization to confirm the differential signals, the cDNA inserts of the isolated clones were amplified by PCR and subjected to DNA sequence analysis. The identity of the cDNA clones was then revealed by searching for any homology with the EMBL/GenBank data base. Five cDNA clones were isolated from the initial screening of 10,000 phage clones. Among them, two were novel genes. One clone was identified to be a gene encoding for the heavy chain of $\mathrm{IgG}$, which was presumably derived from plasma cells. Furthermore, it was very interesting to find that the other two clones showed 99.0 and $96 \%$ homologies to the sequences of the genes encoding human L-ferritin and H-ferritin, respectively. The high expression of the ferritin genes in human atherosclerotic aortas was further confirmed by Northern blot analysis. As shown in Fig. $1 A$, the expression of both L-ferritin and $\mathrm{H}$-ferritin mRNAs was at least 10 -fold higher in human atherosclerotic aorta than in normal aorta. Similarly, atherosclerotic aortic arch induced in rabbits by a high cholesterol diet also exhibited significantly higher expression of ferritin genes than the normal rabbit aorta control (Fig. $1 \mathrm{~B}$ ).

To address the question of whether the induction of ferritin genes is correlated with the development of atherosclerotic lesions, a time course experiment was conducted to examine the expression levels of both ferritin genes in rabbits fed with a high cholesterol diet for various times. As shown in Fig. $2 \mathrm{~A}$, plaque was clearly formed in the aorta of the animals only after 6 wk of feeding with a high cholesterol diet. Likewise, the expression of both L- and $\mathrm{H}$-ferritin genes in the aorta did not significantly increase until $6 \mathrm{wk}$ of high cholesterol diet (Fig. 2 $B)$. This result clearly illustrates that the induction of ferritin expression parallels the progression of lesion formation. A similar time course was seen for the induction of monocyte chemoattractant protein-1 (MCP-1), which is one of several highly expressed genes detected in atherosclerotic plaques (12) (Fig. 2 B). Besides in the aortic arch, the increased expression of ferritin genes was also found in the abdominal aorta and thoracic aorta of cholesterol-fed rabbits (Fig. 3), although the degrees of induction varied among different sections of aorta.

Localization of the induced ferritin genes in lesions by in situ hybridization. To further examine the cellular localization of the induced ferritin genes, in situ hybridization with atherosclerotic lesions of human aortas was performed. As illustrated in Fig. 4, both L- and $\mathrm{H}$-ferritin mRNAs were shown to be present mainly on the thickened intima of the human fatty streak. Immunostaining of the serial sections with specific antibody to human macrophage demonstrated that the cells responsible for the expression of both ferritin genes are macrophages. Positive hybridization signals were also detected on a few of the endothelial cells as shown in the same figure. There was no signal detected in the medial smooth muscle cells. In all of the three human early lesions examined, the expression of both ferritin mRNAs in macrophages was prominent. However, the signals in endothelial cells were detectable only in two of the lesions, indicating that macrophage is the major cell type for the induction of ferritin genes in early lesions. When the in situ hybridization was performed with human advanced atherosclerotic lesions, both L- and $\mathrm{H}$-ferritin mRNA signals were detected in areas rich in smooth muscle cells as revealed by the immunoreactivity with specific antibody to $\alpha$-actin (Fig. 5). The expression of ferritin mRNAs in smooth muscle cells was observed in all of the four advanced lesions examined. However, the hybridization signals in macrophages, which were found scattered along the lipid core of the advanced lesions, were markedly diminished (data not shown). This observation indicates that the ferritin gene induc-

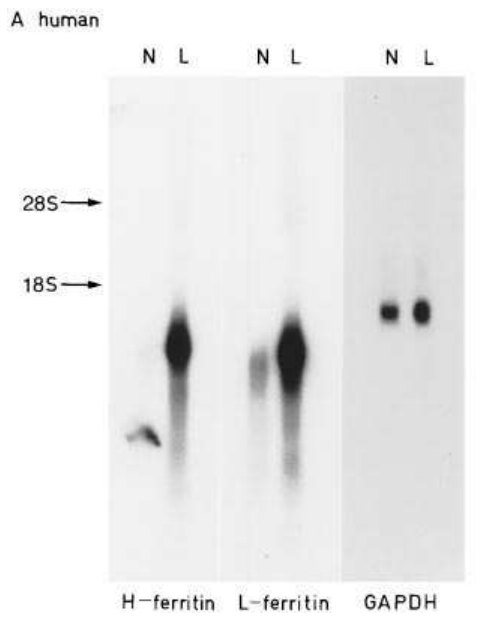

Figure 1. Northern blots showing the differential expression levels of L-ferritin and H-ferritin mRNAs in normal $(N)$ and atherosclerotic $(L)$ aortas from humans $(A)$ and rabbits $(B)$. Total RNAs were isolated and subjected to electrophoresis on $1 \%$ agarose gel containing formaldehyde. After transferring onto nylon membranes, the RNAs were hybridized with ${ }^{32} \mathrm{P}$-labeled cDNA probe of L-ferritin, H-ferritin, or GAPDH (internal control). The positions of the $28 \mathrm{~S}$ and $18 \mathrm{~S}$ rRNA are marked with arrows. 
A

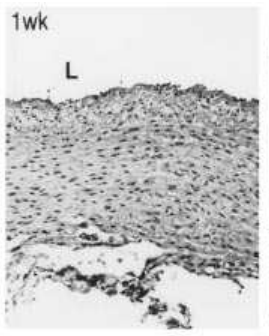

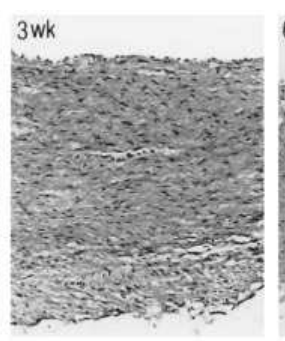

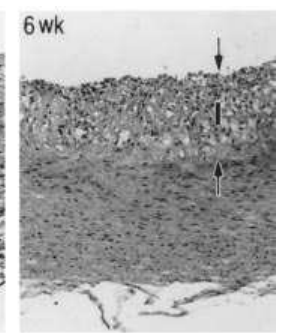

B

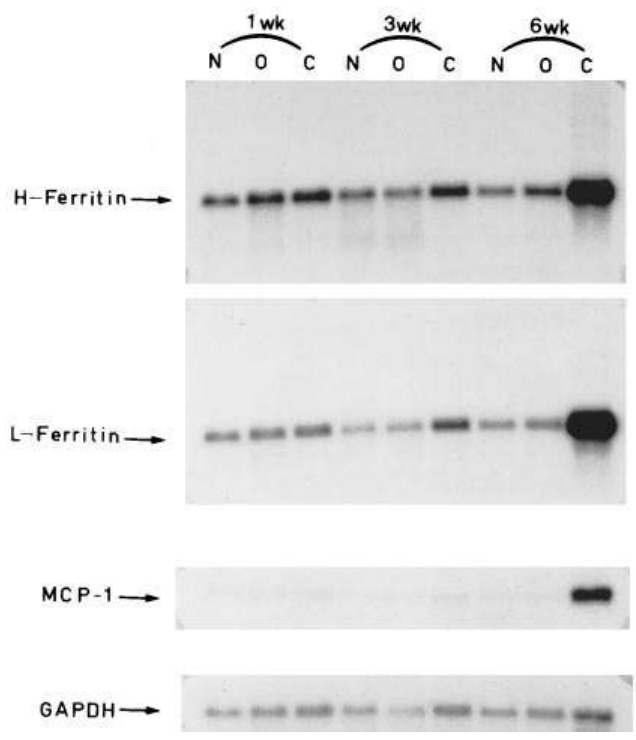

Figure 2. Time-course of increased ferritin gene expression in aortas of rabbits fed with a high cholesterol diet. $(A)$ Hematoxylin-eosin staining of the aortic arches from rabbits fed with high cholesterol diet for 1,3 , and $6 \mathrm{wk}$, respectively. Lumen $(L)$ is on the top. The thickened intima $(I)$ in aorta is marked by arrows, $\times 40$. $(B)$ Total RNAs were isolated from the aortic arches of four rabbits in each group and subjected to Northern blot analysis with ${ }^{32} \mathrm{P}$-labeled cDNA probe of $\mathrm{H}$-ferritin, L-ferritin, MCP-1, or GAPDH as indicated. $N, O$, and $C$ refer to the animal groups fed with regular diet, regular diet supplemented with $6 \%$ corn oil, and regular diet supplemented with $6 \%$ corn oil plus $2 \%$ cholesterol, respectively.

tion during the later stage of lesion progression occurs mainly in smooth muscle cells.

Iron histochemistry and ferritin immunocytochemistry. To elucidate the potential involvement of iron in the up-regulation of ferritin expression (25), the presence of iron in atherosclerotic lesions was examined by Perls' reaction. As illustrated in Fig. $6 B$, no positive staining was detected in the early lesion of rabbit aorta. Similarly, iron staining was not detected in human early fatty streak (Fig. $6 C$ ), although immunostaining of the serial sections with specific antibody to human ferritin revealed strong immunoreactivity on the thickened intima (Fig. 6, $D$ and $E$ ). In parallel with the gene expression revealed by in situ hybridization, the induced ferritin protein in early lesion was mainly detected in macrophages of the intima and some of the endothelial cells (Fig. $6 E$ ). When Perls' reaction was performed with human advanced lesion, it was very interesting to
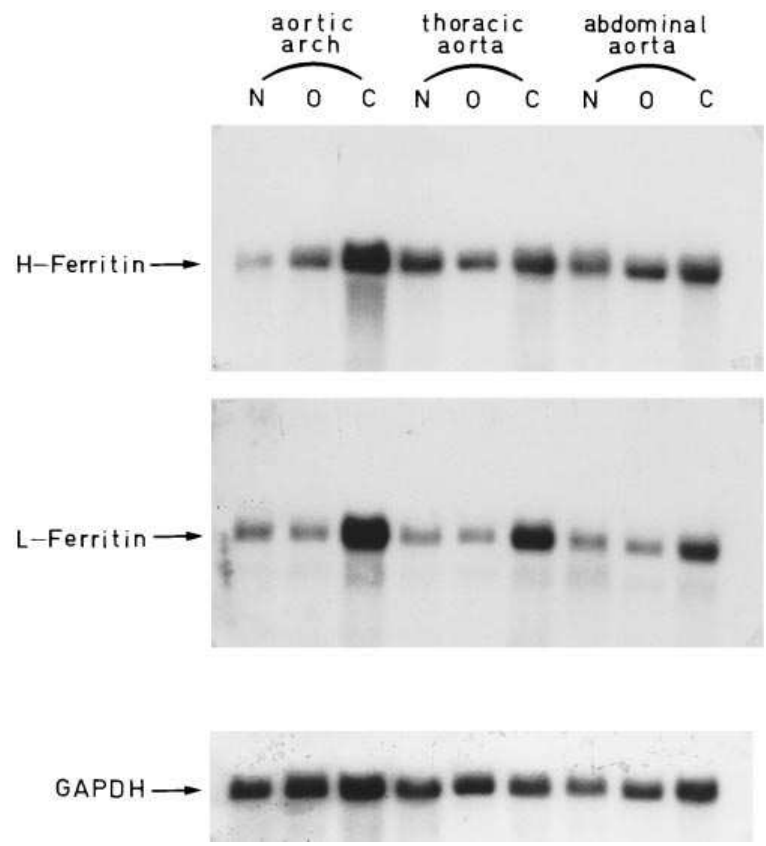

Figure 3. Increased ferritin gene expression in various sections of aortas of the rabbits fed with a high cholesterol diet for $6 \mathrm{wk}$. The total RNAs were isolated from indicated parts of the aortas, and Northern blot was performed as described in Methods. $N, O$, and $C$ refer to the animal groups fed with regular diet, regular diet supplemented with $6 \%$ corn oil, and regular supplemented with $6 \%$ corn oil plus $2 \%$ cholesterol, respectively.

observe that a strong positive reaction appeared in the area that colocalized with the strong ferritin immunoreactivity (Fig. 7). These results imply that iron is not responsible for the induction of ferritin gene expression in the early course of plaque formation. Nevertheless, deposition of iron in lesion appeared to be subsequently augmented, which may be, in part, due to the increased ferritin in the late stage of atherosclerosis.

Regulation of ferritin gene expression in cultured human monocytic THP-1 cells and aortic smooth muscle cells. The expression of ferritin genes is subjected to regulation by cytokines in a number of cell types, including adipocytes, myoblasts, and monocytes (26-29). To elucidate the possible mechanisms responsible for the elevated ferritin gene expression in atherosclerotic lesions, we examined the effects of cytokines, including IL-1, TNF, TGF, and PDGF on the mRNA levels of L-and H-ferritin in cultured human THP-1 and aortic smooth muscle cells. As shown in Fig. 8 A, treatment of THP-1 cells with TNF for $24 \mathrm{~h}$ significantly increased in mRNA levels of MCP-1 and both ferritins. On the other hand, IL-1, TGF, and PDGF exerted no effect on mRNAs of MCP-1 or ferritin genes under the same incubation conditions. The effect of oxidized LDL, which is present in the lesions and exerts atherogenic activity (30) on ferritin gene expression was also examined. Oxidized LDL increased MCP-1 expression but did not affect the expression of either ferritin gene (Fig. $8 \mathrm{~A}$ ). The fact that oxidized LDL was ineffective at inducing ferritin gene expression was not due to the presence of the antioxidant, BHT, which was added during the preparation of oxidized LDL, in the culture medium, since BHT alone at the same concentration $(0.8 \mu \mathrm{M})$ or the dialyzed oxidized LDL preparation de- 

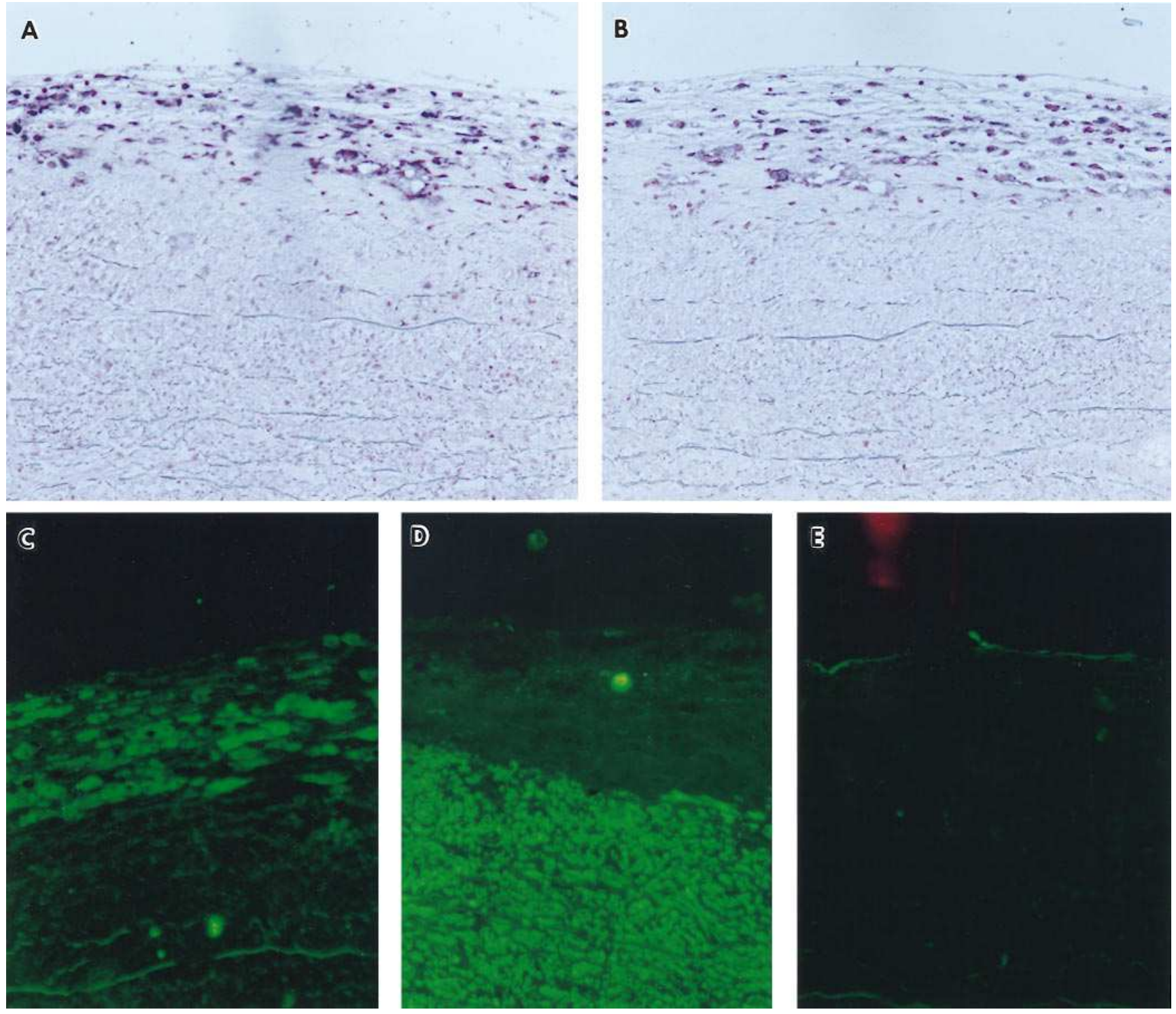

Figure 4. Cellular localization of ferritin gene expression in a fatty streak of human ascending aorta. Immunostaining and in situ hybridization of serial sections $(A-E)$ : $(A)$ in situ hybridization with DIG-labeled H-ferritin antisense-RNA; $(B)$ in situ hybridization with DIG-labeled L-ferritin antisense-RNA; $(C)$ antibody specific for human macrophages (CD68, dilution 1:50); $(D)$ antibody specific for human smooth muscle cells $(\alpha$-actin, dilution 1:25); $(E)$ antibody specific for endothelial cells (vWf, dilution 1:20). Controls for immunostaining and in situ hybridization were negative (data not shown). $A$ and $B$ were counterstained with carmin red. $\times 100$.

void of BHT did not affect the levels of both ferritin mRNAs (data not shown). On the other hand, the expression of H-ferritin mRNA, but not L-ferritin mRNA, was induced by two to threefold after treatment with TNF or IL-1 in aortic smooth muscle cells (Fig. 8 B). Again, TGF, PDGF, and oxidized LDL did not show any effect on the expression of either ferritin gene.

\section{Discussion}

By differentially screening a cDNA library of human atherosclerotic aorta, we have identified that genes for the iron-storage proteins, L-ferritin and $\mathrm{H}$-ferritin, are highly expressed in human atherosclerotic vessels. A similar result was found in atherosclerotic aorta obtained from rabbits which were fed a high cholesterol diet. Time course study of aorta from the rab- bits further revealed a close association between lesion formation and increased ferritin gene expression. As demonstrated in Fig. 2, the induction of ferritin genes in the rabbits was not prominent until $6 \mathrm{wk}$ after they had started eating a high fat diet, which paralleled the expression of the MCP-1 gene and formation of plaque characterized as early fatty streak. This observation suggests that the induction of ferritin genes occurs in the early phase of progression of lesions. Furthermore, it was interesting to notice that the degree of the ferritin gene expression in various parts of the aortas in the high cholesterol diet-fed rabbits (Fig. 3) was in parallel to the severity of the lesions found in the different areas (data not shown).

In mammalian cells, ferritin is known to exist as a high molecular mass complex composed of 24 subunits of $\mathrm{H}$ - and L-ferritin. $\mathrm{H}$ - and L-ferritins are derived from two distinct 

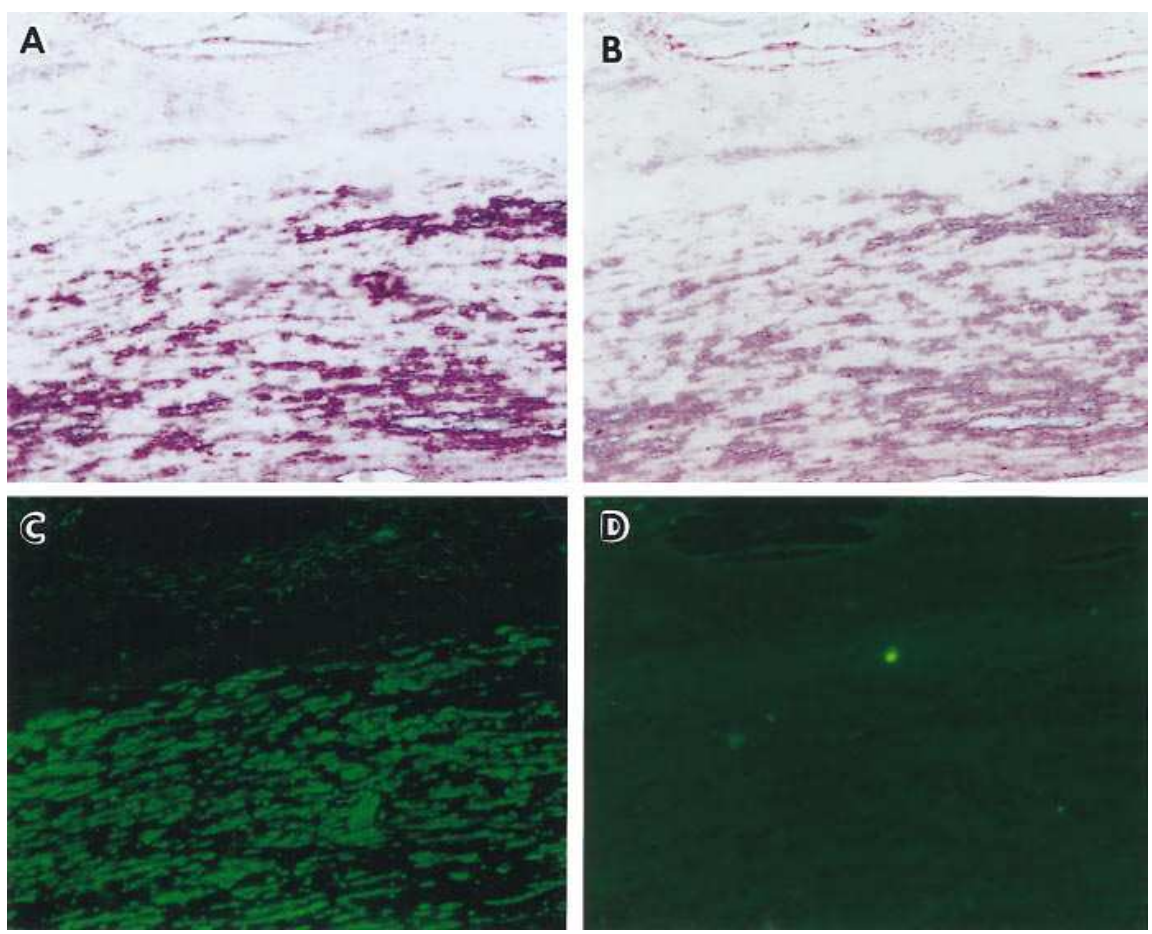

Figure 5. Ferritin gene expression in smooth muscle cells of advanced atherosclerotic lesion of human abdominal aorta. Immunostaining and in situ hybridization of serial sections $(A-D):(A)$ in situ hybridization with DIG-labeled $\mathrm{H}$-ferritin antisense RNA; $(B)$ in situ hybridization with DIG-labeled L-ferritin antisense RNA; $(C)$ antibody specific for human smooth muscle cells $(\alpha$-actin, dilution 1:25); $(D)$ negative control for immunostaining. $\times 100$. genes and show only $\sim 50 \%$ homology in primary amino acid sequences (17). The $\mathrm{H} / \mathrm{L}$ ferritin ratio varies widely in different tissues and cells. L-chain-rich ferritin predominates in ironstorage organs, such as liver and spleen; while H-chain-rich ferritin predominates in organs of low iron content, such as heart and pancreas. Since $\mathrm{H}$-ferritin can bind and release iron more easily than L-ferritin, it is generally believed that $\mathrm{H}$-ferritin plays a key role in intracellular iron transport, whereas L-ferritin is associated with iron storage (17). As a whole, the main function of ferritin is the storage and delivery of iron for intracellular use. Alternatively, it functions as a chelator sequestering intracellular unbound iron, particularly ferrous iron which is toxic to cells by acting as a strong in vivo catalyst for oxidative free radical reaction (31). The antioxidant role of ferritin was shown to be closely associated with the intrinsic ferroxidase activity, which converts ferrous iron to ferric iron, in H-ferritin (32). Regulation of ferritin gene expression can occur at multiple levels. It is well documented that biosynthesis of ferritin is regulated by iron at the translational level (25). When intracellular iron concentration is low, synthesis is repressed through the interaction between an iron-responsive element, which is located in the $5^{\prime}$-untranslated region of both $\mathrm{L}-$ and $\mathrm{H}$-ferritin mRNAs, and a $90-\mathrm{kD}$ repressor protein. Increased intracellular iron would lead to the release of the repressor protein and permit subsequent translation of the mRNAs. In some cell types, expression of L-ferritin gene has also been shown to be regulated by iron at the transcriptional level $(33,34)$.

In addition to iron, increased ferritin gene expression was also observed in other circumstances, including cell differentiation, proliferation, inflammation, and specific hormonal signals (35-38). Recently, a number of studies have demonstrated an increase in ferritin synthesis after induction of heme oxygenase in different types of cultured cells, including endothelial cells, subjected to oxidative stress $(32,39-42)$. The increased iron pool derived from the degradation of heme by heme oxygenase was mainly responsible for the increased ferritin expression, primarily at a translational level. It was shown that the newly synthesized apoferritin acts as an antioxidant to protect cells from further insult through its iron-sequestration capability. In contrast to the cytoprotective role, other studies, however, have shown that ferritin is a source of active catalytic iron causing oxidative damage by the fact that superoxide radicals generated by stimulated cells would subsequently cause the release of iron from ferritin (43). A recent study on an in vivo animal model has shown that liver ferritin can represent either a pro- or an antioxidant in a time-dependent manner in rats subjected to oxidative stress (42). It appears that the functional role of ferritin in cells during oxidative insults is circumstantial. Currently, the oxidation of LDL in the subendothelial space is recognized as one of the early events in atherogenesis (30). In vitro studies have shown that LDL is subjected to oxidative modification in culture by a range of cell types, including endothelial cells (44), arterial smooth muscle cells (45), as well as macrophages (46), and is subsequently taken up through the scavenger receptors by macrophages to become foam cells which are the pathological hallmark of early atherosclerotic lesions $(1,2)$. It has been shown that small amounts of iron are an absolute requirement for oxidation of LDL by cultured cells, suggesting the involvement of iron in LDL oxidation. This notion is supported by a recent study by Smith et al. (47), who showed that the interior of advanced human atherosclerotic lesions provides a highly pro-oxidant environment, containing iron and copper ions which are available to catalyze free radical reactions as well as lipid oxidation. Recently, studies on human subjects have shown that the serum ferritin concentration, which reflects the level of total body iron stores, was positively correlated with a high risk of cardiovascular disorders, such as acute myocardial infarction (48) and carotid atherosclerosis (49). Although the physiological relevance of 

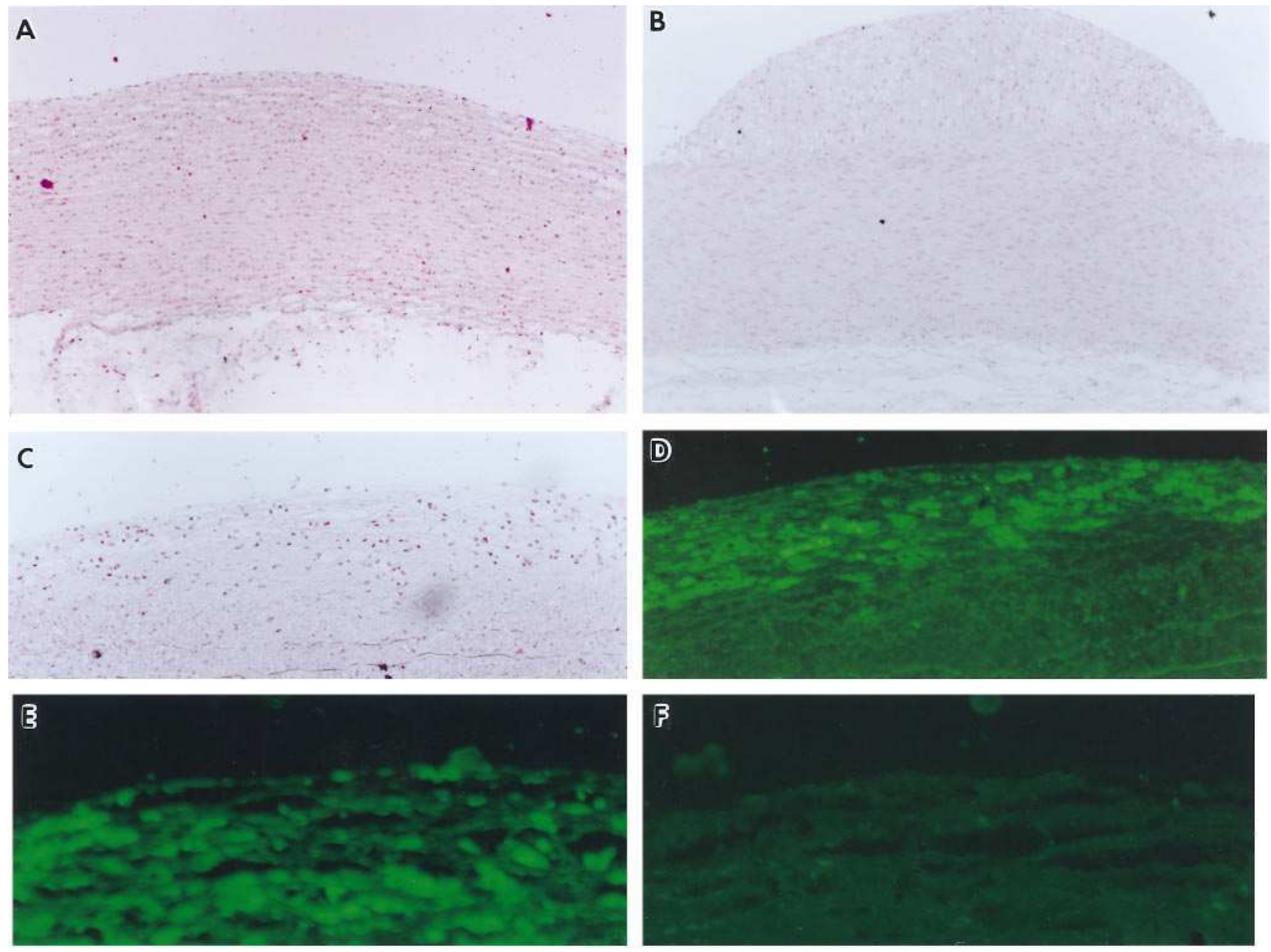

Figure 6. Perls' iron staining and ferritin immunostaining in early lesions. Perls' iron staining with DAB intensification were performed on $(A)$ rabbit normal aorta, $(B)$ rabbit aortic fatty streak, and $(C)$ human aortic fatty streak. $(D$ and $E)$ Immunostaining was performed on serial sections of human atherosclerotic aorta with antibody specific for human ferritin (dilution 1:100). (F) Negative control for immunostaining. $A$ and $B, \times 40 ; C$ and $D, \times 100 ; E$ and $F ; \times 200$.

the increased level of serum ferritin in atherosclerosis remains to be clarified, the present study has provided strong evidence to support the implication of iron-storage proteins in the progression of the disease. Consistent with the present observation, a recent report by Juckett et al. has also demonstrated the presence of increased immunoreactive ferritin in human coronary atherosclerotic lesions, although no iron deposition was detected in their study (50).

By both in situ hybridization and immunocytochemistry, the induced L- and H-ferritin genes were shown to be located mainly in macrophages and some of the endothelial cells of the thickened intima in the human early atherosclerotic lesion (Fig. 4), while both signals were detected mainly in smooth muscle cells of advanced lesions (Fig. 5). The increase in expression of ferritin protein in early lesion, as demonstrated by immunostaining, however, was not accompanied by the augmented iron deposition as examined by Perls' Prussian blue reaction (Fig. 6). This result suggests that iron, which is known to up-regulate ferritin biosynthesis at the transcriptional or posttranscriptional level (25), is not the primary cause leading to the induction of ferritin gene expression in the atherosclerotic lesion. Conversely, the newly synthesized ferritins present in early lesion appeared to be apoproteins, which might serve as intracellular chelators for free iron to protect cells from further oxidative damage caused by iron overload or other stress conditions and limit the propagation of the tissue injury. However, when the plaque progressed to a more severe lesion, iron deposition became evident in areas rich in ferritins, indicating that the ferritins were subsequently laden with iron along with the progression of the lesion. Since the vascular damage would be augmented in the late stage of atherosclerosis, it is speculative that the presence of iron-bound ferritin at sites of damage in which increased superoxide formation occurs might in turn lead to increased oxidative insults. Apparently, the paradoxical roles of ferritin implicated in atherogenesis will largely depend upon the stage of the atherosclerotic lesion and the status of iron loading within ferritin macromolecules.

Previous studies in a number of cell systems have demonstrated that the expression of ferritin genes is up-regulated after stimulation by cytokines (26-29). Increased cytokine generation after the activation of monocytes and endothelial cells has been observed in the early phase of plaque formation (51). To elucidate whether cytokines are responsible for inducing ferritin genes in atherosclerotic lesions, we cultured human 

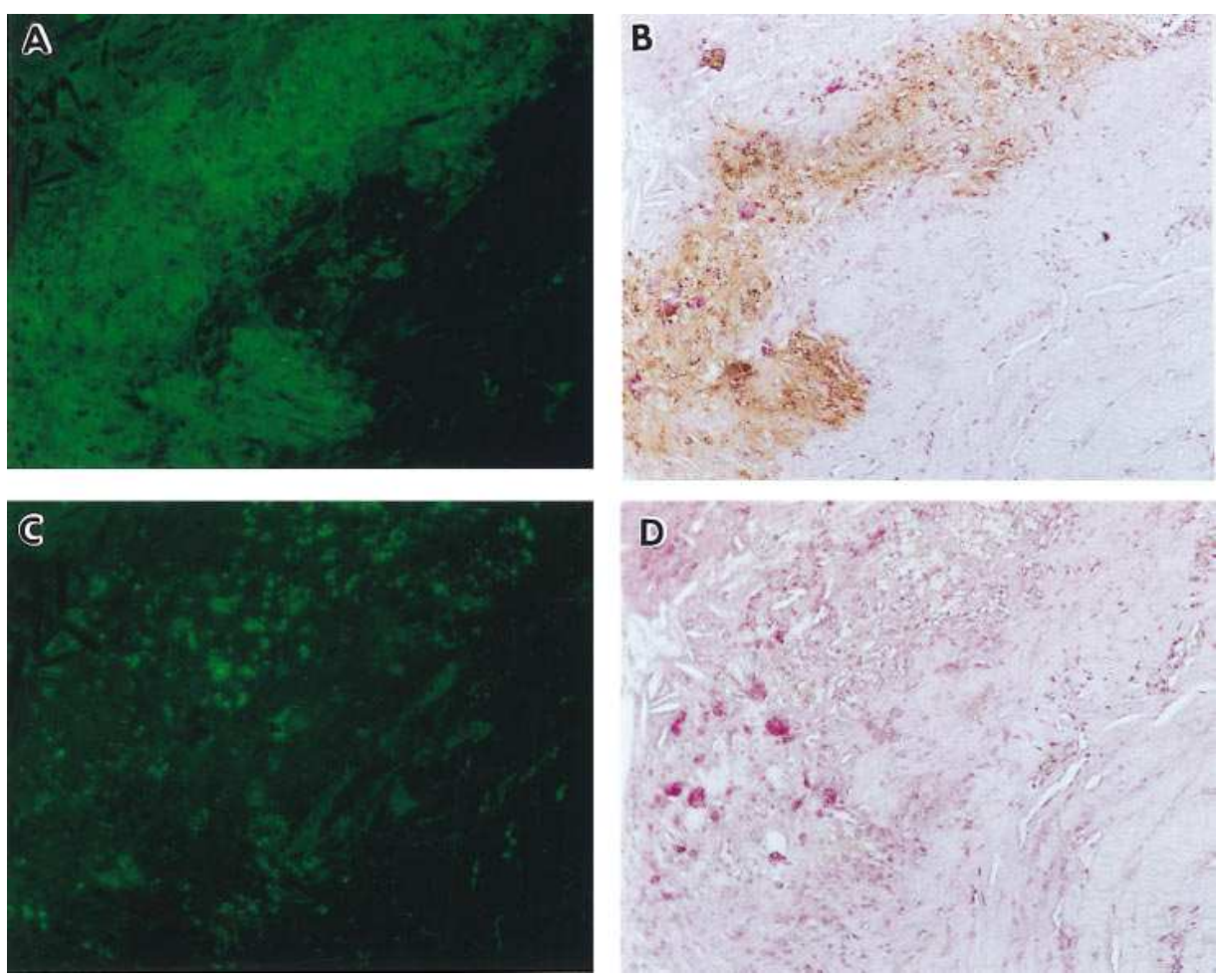

Figure 7. Colocalization of ferritin protein and iron aggregates in advanced human atherosclerotic lesion. Immunostaining and Perls' iron staining of serial sections of human atherosclerotic aorta $(A-D):(A)$ antibody specific for human ferritin (dilution 1:100); $(B)$ Perls' reaction with DAB intensification; $(C)$ negative control for immunostaining; $(D)$ negative control for iron staining. $B$ and $D$ were counterstained with carmin red. $\times 100$. monocytic THP-1 cells and aortic smooth muscle cells and examined the effects of various cytokines, including IL-1, TNF, TGF, and PDGF on the ferritin mRNA levels in these cells. Consistent with observations in myoblasts and adipocytes, IL-1 and TNF significantly augmented the expression of the $\mathrm{H}$-ferritin gene without having much effect on the L-ferritin gene in aortic smooth muscle cells. In contrast, L- and H-ferritin genes were up-regulated to different extents in THP-1 cells after treatment with TNF. Furthermore, IL-1 affected neither ferritin gene in these monocytic cells. Nevertheless, TGF and PDGF did not show any effect on either ferritin gene in both cell lines. A further experiment with oxidized LDL again demonstrated that the atherogenic agent commonly present in atherosclerotic lesions (30) did not effectively alter ferritin gene expression under our experimental conditions. These results suggest that the expressions for L-ferritin and
$\mathrm{H}$-ferritin genes are subject to differential regulation in different cell types as the plaque progresses.

In summary, the present study clearly demonstrates the high expression of ferritin genes in atherosclerotic lesions. The induction is closely associated with the development of plaques. Although the physiological relevance of ferritin in atherogenesis is not yet fully understood, it is conceivable that increased expression of the iron-binding protein in atherosclerotic lesion would affect the progression of the disease.

\section{Acknowledgments}

The authors thank Dr. Cathy Fletcher and Ms. Jane Sugden for editorial assistance.

This work was supported by grant NSC 85-2331-B-001-019 from the National Science Council, Taiwan, R.O.C.
A THP-1

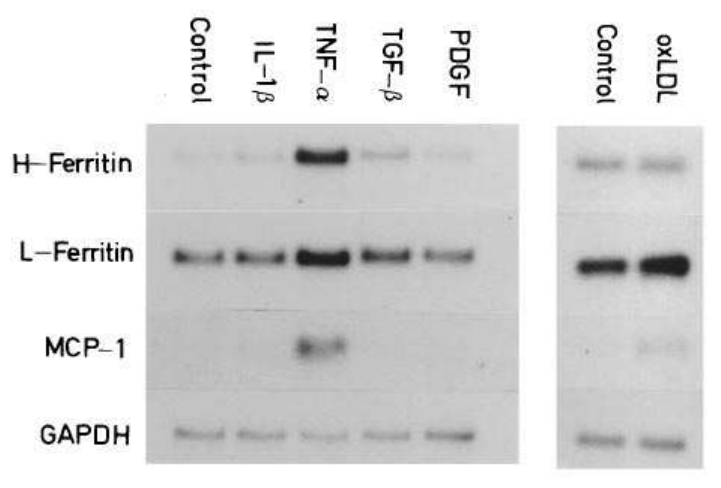

B HA-VSMC

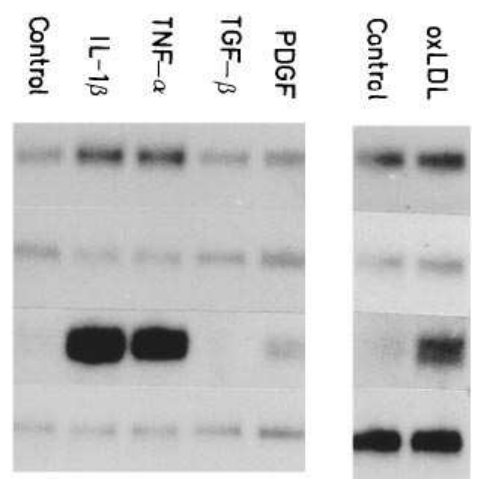

Figure 8. Effects of cytokines and oxidized LDL on ferritin gene expression in cultured human monocytic THP-1 $(A)$ and human vascular aortic smooth muscle cells $(B)$. Cultured cells were treated without (Control) or with IL-1 (25 ng/ml), TNF (10 ng/ml), TGF (5 ng/ $\mathrm{ml})$, PDGF $(2.5 \mathrm{ng} / \mathrm{ml})$, or oxidized LDL $(20 \mu \mathrm{g} / \mathrm{ml})$ for $24 \mathrm{~h}$. Total RNAs were isolated and Northern blot analysis with indicated cDNA probe was performed. 


\section{References}

1. Ross, R. 1986. The pathogenesis of atherosclerosis: an update. N. Engl. J. Med. 314:488-500.

2. Ross, R. 1993. The pathogenesis of atherosclerosis: a perspective for the 1990s. Nature (Lond.). 362:801-809.

3. Ross, R., J. Masuda, E.W. Raines, A.M. Gown, S. Katsuda, M. Sasahara, T. Malden, H. Masuko, and H. Sato. 1990. Localization of PDGF-B protein in macrophages in all phases of atherogenesis. Science (Wash. DC). 248:10091012.

4. Rosenfeld, M.E., S. Ylä-Herttuala, B.A. Lipton, A.O. Virginia, J.L. Witztum, and D. Steinberg. 1992. Macrophage colony-stimulating factor mRNA and protein in atherosclerotic lesions of rabbits and human. Am. J. Pathol. 140:291300 .

5. Winkles, J.A., G.F. Alberts, E. Brogi, and P. Libby. 1993. Endothelin-1 and endothelin receptor mRNA expression in normal and atherosclerotic human arteries. Biochem. Biophys. Res. Commun. 31:1081-1088.

6. Brogi, E., J.A. Winkles, R. Underwood, S.K. Clinton, G.F. Alberts, and P. Libby. 1993. Distinct patterns of expression of fibroblast growth factors and their receptors in human atheroma and nonatherosclerotic arteries. Association of acidic FGF with plaque microvessels and macrophages J. Clin. Invest. 92: 2408-2418.

7. Ylä-Herttuala, S., M.E. Rosenfeld, S. Parthasarathy, E. Sigal, T. Sarkioja, J.L. Witztum, and D. Steinberg. 1991. Gene expression in macrophage-rich human atherosclerotic lesions: 15-lipoxygenase and acetyl LDL receptor mRNA colocalized with oxidation-specific lipid-protein adducts. J. Clin. Invest. 87: 1146-1152.

8. Luoma, J., T. Hiltunen, T. Sarkioja, S.K. Moestrup, J. Gliemann, T. Kodama, T. Nikkari, and S. Ylä-Herttuala. 1994. Expression of $\alpha 2$-macroglobulin receptor/low density lipoprotein receptor-related protein and scavenger receptor in human atherosclerotic lesions. J. Clin. Invest. 93:2014-2021.

9. Cybulsky, M.I., and M.A. Gimbrone, Jr. 1991. Endothelial expression of a mononuclear leukocyte adhesion molecule during atherogenesis. Science (Wash. DC). 251:788-791.

10. Couffinhal, T., C. Duplaa, C. Moreau, J.M. Lamaziere, and J. Bonnet. 1994. Regulation of vascular cell adhesion molecule-1 and intracellular adhesion molecule-1 in human vascular smooth muscle cells. Circ. Res. 74:225-234.

11. Carlos, T.M., and J. Harlan. 1990 Membrane proteins involved in phagocyte adherence to endothelium. Immunol. Rev. 114:5-28.

12. Ylä-Herttuala, S., B.A. Lipton, M.E. Rosenfeld, T. Sarkioja, T. Yoshimura, E.J. Leonard, J.L. Witztum, and D. Steinberg. 1991. Expression of monocyte chemoattractant protein 1 in macrophage rich areas of human and rabbit atherosclerotic lesions. Proc. Natl. Acad. Sci. USA. 88:5252-5256.

13. Koch, A.E., S.L. Kunkel, W.H. Pearce, M.R. Shah, D. Parikn, H.L. Evanoff, G.K. Haines, M.D. Burdick, and R.M. Strieter. 1993. Enhanced production of the chemotactic cytokines interleukin- 8 and monocyte chemoattractant protein-1 in human abdominal aortic aneurysms. Am. J. Pathol. 142:1423-1431.

14. Fisher, G.M., M.L. Swain, and K. Cherian. 1980. Increased vascular collagen and elastin synthesis in experimental atherosclerosis in the rabbit: variation in synthesis among major vessels. Atherosclerosis. 35:11-20.

15. Shanahan, C.M., N.R.B. Cary, J.C. Metcalfe, and P.L. Weissberg. 1994. High expression of genes for calcification-regulating proteins in human atherosclerotic plaques. J. Clin. Invest. 93:2393-2402.

16. O'Brien, E.R., M.R. Garvin, D.K. Stewart, T. Hinohara, J.B. Simpson, S.M. Schwartz, and C.M. Giachelli. 1994. Osteopontin is synthesized by macrophage smooth muscle and endothelial cells in primary and restenotic human coronary atherosclerotic plaques. Arterioscler. Thromb. 14:1648-1656.

17. Theil, E.C. 1987. Ferritin: structure, gene regulation, and cellular function in animals, plants, and microorganisms. Annu. Rev. Biochem. 56:289-315.

18. Chomczynski, P., and N. Sacchi. 1987. Single-step method of RNA isolated by acid guanidium thiocyanate-phenol-chloroform extraction. Anal. Biochem. 162:156-159.

19. Aviv, H., and P. Leder. 1972. Purification of biologically active globin messenger RNA by chromatography on oligothymidylic acid-cellulose. Proc. Natl. Acad. Sci. USA. 69:1408-1412.

20. Maniatis, T., E.F. Fritsch, and J. Sambrook. 1982. Molecular Cloning. A Laboratory Manual. Cold Spring Harbor Laboratory, Cold Spring Harbor, New York. 545 pp.

21. Sassoon, D., and N. Rosenthal. 1993. Detection of messenger RNA by in situ hybridization. In Methods in Enzymology. J.N. Abelson and M.I. Simon, editors. Academic Press, Inc., San Diego. 384-404.

22. Hill, J.M., and R.C. Switzer. 1984. The regional distribution and cellular localization of iron in the rat brain. Neuroscience. 11:595-603.

23. Hughes, H., B. Mathews, M.L. Lenz, and J.R. Guyton. 1994. Cytotoxicity of oxidized LDL to porcine aortic smooth muscle cells is associated with the oxysterols 7-ketocholesterol and 7-hydroxycholesterol. Arterioscler. Thromb. 14:1177-1185.

24. Koch, A.E., G.K. Haines, R.J. Rizzo, J.A. Radosevich, R.M. Pooe, P.G. Robinson, and W.H. Pearce. 1990. Human abdominal aortic aneurysms. Immunophenotypic analysis suggesting an immune-mediated response. Am. J. Pathol. 137:1199-1213.
25. Munro, H.N. 1990. Iron regulation of ferritin gene expression. J. Cell. Biochem. 44:107-115.

26. Torti, S.V., E.L. Kwak, S.C. Miller, L.L. Miller, G.M. Ringold, K.B. Myambo, A.P. Young, and F.M. Torti. 1988. The molecular cloning and characterization of murine ferritin heavy chain, a tumor necrosis factor-inducible gene. J. Biol. Chem. 263:12638-12644.

27. Miller, L.L., S.C. Miller, S.V. Torti, Y. Tsuji, and F.M. Torti. 1991. Ironindependent induction of ferritin $\mathrm{H}$ chain by tumor necrosis factor. Proc. Natl. Acad. Sci. USA. 88:4946-4950.

28. Wei, Y., S.C. Miller, Y.Tsuji, S.V. Torti, and F.M. Torti. 1990. Interleukin-1 induces ferritin heavy chain in human muscle cells. Biochem. Biophys. Res. Commun. 169:289-296.

29. Fahmy, M., and S.P. Young. 1993. Modulation of iron metabolism in monocyte cell line U937 by inflammatory cytokines: changes in transferrin uptake, iron handling and ferritin mRNA. Biochem. J. 296:175-181.

30. Witztum, J.L., and D. Steinberg. 1991. Role of oxidized low density lipoprotein in atherogenesis. J. Clin. Invest. 88:1785-1792.

31. Rice-Evans, C., and R. Burdon. 1993. Free radical-lipid interactions and their pathological consequences. Prog. Lipid Res. 32:71-110.

32. Balla, G., H.S. Jacob, J. Balla, M. Rosenberg, K. Nath, F. Apple, J.W. Eaton, and G.M. Vercellotti. 1992. Ferritin: a cytoprotective antioxidant stratagem of endothelium. J. Biol. Chem. 276:18148-18153.

33. Cairo, G., L. Bardella, L. Schiaffonati, P. Arosio, S. Levi, and A. Bernelli-Zazzera. 1985. Multiple mechanisms of iron-induced ferritin synthesis in HeLa cells. Biochem. Biophys. Res. Commun. 133:314-321.

34. White, K., and H.N. Munro. 1988. Induction of ferritin synthesis by iron is regulated at both the transcriptional and translational levels. J. Biol. Chem. 263:8938-8942.

35. McClarty, G.A., A.K. Chan, B.K. Choy, and J.A. Wright. 1990. Increased ferritin gene expression is associated with increased ribonucleotide reductase gene expression and the establishment of hydroxyurea resistance in mammalian cells. J. Biol. Chem. 265:7539-7547.

36. Chazenbalk, G.D., H.L.Wadsworth, and B. Rapoport. 1990. Transcriptional regulation of ferritin $\mathrm{H}$ messenger RNA levels in FRTL5 rat thyroid cells by thyrotropin. J. Biol. Chem. 265:666-670.

37. Liau, G., L.M. Chan, and P. Feng. 1991. Increased ferritin gene expression is both promoted by cAMP and a marker of growth arrest in rabbit vascular smooth muscle cells. J. Biol. Chem. 266:18819-18826.

38. Miller, L.L., S.C. Miller, S.V. Torti, Y. Tsuji, and F.M. Torti. 1991. Ironindependent induction of ferritin $\mathrm{H}$ chain by tumor necrosis factor. Proc. Natl. Acad. Sci. USA. 88:4946-4950.

39. Vile, G.F., and R.M. Tyrrell. 1993. Oxidative stress resulting from ultraviolet A irradiation of human skin fibroblasts leads to a heme oxygenasedependent increase in ferritin. J. Biol. Chem. 268:14678-14681.

40. Vile, G.F., S. Basu-Modak, C. Waltner, and R.M. Tyrrell. 1994. Heme oxygenase 1 mediates an adaptive response to oxidative stress in human skin fibroblasts. Proc. Natl. Acad. Sci. USA. 91:2607-2610.

41. Balla, J., H.S. Jacob, G. Balla, K. Nath, J.W. Eaton, and G.M. Vercellotti. 1993. Endothelial cell heme uptake from heme proteins: induction of sensitization and desensitization to oxidant damage. Proc. Natl. Acad. Sci. USA. 90:9285-9289.

42. Cairo, G., L. Tacchini, G. Pogliaghi, E. Anzon, A. Tomasi, and A. Bernelli-Zazzera. 1995. Induction of ferritin synthesis by oxidative stress. Transcriptional and post-transcriptional regulation by expression of the free iron pool. J. Biol. Chem. 270:700-703.

43. Reif, D.W. 1992. Ferritin as a source of iron for oxidative damage. Free Radical Biol. \& Med. 12:417-427.

44. Morel, D.W., P.E. DiCorleto, and G.M. Chisolm. 1984. Endothelial and smooth muscle cells alter low density lipoprotein in vitro by free radical oxidation. Arteriosclerosis. 4:357-364.

45. Heinecke, J.W., L. Baker, H. Rosen, and A. Chait. 1986. Superoxidemediated modification of low density lipoprotein by arterial smooth muscle cells. J. Clin. Invest. 77:757-761.

46. Henriksen, T., E.M. Mahoney, and D. Steinberg. 1983. Enhanced macrophage degradation of biologically modified low density lipoprotein. Arteriosclerosis. 3:149-159.

47. Smith, C., M.J. Mitchinson, O.I. Aruoma, and B. Halliwell. 1992. Stimulation of lipid peroxidation and hydroxyl-radical generation by contents of human atherosclerotic lesions. Biochem. J. 286:901-905.

48. Salonen, J.T., K. Nyyssonen, H. Korpela, J. Tuomilehto, R. Seppanen, and R. Salonen. 1992. High stored iron levels are associated with excess risk of myocardial infarction in eastern Finnish men. Circulation. 86:803-811.

49. Kiechl, S., F. Aichner, F. Gerstenbrand, G. Egger, A. Mair, G. Rungger, F. Spogler, E. Jarosch, F. Oberhollenzer, and J. Willeit. 1994. Body iron stores and presence of carotid atherosclerosis. Results from the Bruneck study. Arterioscler. Thromb. 14:1625-1630.

50. Juckett, M.B., J. Balla, G. Balla, J. Jessurun, H.S. Jacob, and G.M. Vercellotti. 1995. Ferritin protects endothelial cells from oxidized low density lipoprotein in vitro. Am. J. Pathol. 147:782-789.

51. Kawakami, M., and M. Kuroki. 1993. Roles of cytokines and growth factors in atherogenesis. Jpn. J. Clin. Med. 51(8):2010-2015. 